\title{
Renewable energy consumption in Africa: the role of economic well-being and economic freedom
}

\author{
Anthony Amoah ${ }^{*}$ D, Edmund Kwablah, Kofi Korle and Daniel Offei
}

\begin{abstract}
This study investigates the role of economic well-being and economic freedom as drivers of renewable energy consumption using the share of renewables in total energy consumption in Africa. To achieve this, the study employs a panel data of 32 African countries over the period 1996-2017. To deal with identification challenges associated with panel time-series data, we use the Dynamic Ordinary Least Squares econometric technique. As part of our findings, first, we have evidence that increasing economic well-being in Africa increases the share of renewables in total energy consumption to a point after which it turns negative (inverted $U$ shape). Second, the disaggregated measures of economic freedom show that both property rights and tax burden decrease the share of renewables in total energy consumption. On the contrary, an increase in trade freedom and business freedom measures increases the share of renewables in total energy consumption. Toward the goal of promoting access to affordable, reliable, sustainable, and modern energy for all by 2030, governments in Africa should actively encourage trade freedom and business freedom to enhance the share of renewable energy consumption. Similarly, reducing the tax burden will promote the share of renewable energy consumption. Likewise, we call for further investigation into our evidence of a negative relationship between property rights and the share of renewables in total energy consumption.
\end{abstract}

Keywords: Renewable energy consumption, Economic freedom, HDI, DOLS, FMOLS, OLS, Africa

\section{Background}

The traditional energy supply challenges in the 70 s and $80 \mathrm{~s}$, and climate change concerns, have ignited interest in renewable energy sources. In September 2015, the United Nations set a new target (Sustainable Development Goal \{SDG\} 7) to promote access to affordable, reliable, sustainable, and modern energy for all by 2030. This concerted global effort shows a revived interest in the investment, production, and consumption of cheaper and environmentally friendly sources of energy. Globally, the average consumption of renewable energy has been rising as a result of these efforts. The International Energy Agency (IEA) report [1] predicts that the share of renewables in

\footnotetext{
* Correspondence: aamoah@central.edu.gh

Department of Economics, Central University, Accra, Ghana
}

meeting rising global energy demand will grow by onefifth to reach $12.4 \%$ by 2023 . According to Demirbas [2], the contribution of renewable energy sources to the global energy supply will reach $34.7 \%$ and $47.7 \%$ by 2030 and 2040 , respectively. That is, by the end of 2030, approximately $35 \%$ of the global energy supply will come from renewable sources. This evidence is perhaps a big sigh of relief to proponents of renewable energy use and critics of non-renewable energy use because of climate change concerns and its management challenges.

Figure 1 shows an increasing trend in world renewable energy consumption for most of the sources except traditional biofuels. Hydroelectricity is a primary source of renewable energy globally with emerging sources coming from wind, solar, and biofuel. From 1990 to 1999, in terms

(c) The Author(s). 2020 Open Access This article is licensed under a Creative Commons Attribution 4.0 International License, which permits use, sharing, adaptation, distribution and reproduction in any medium or format, as long as you give appropriate credit to the original author(s) and the source, provide a link to the Creative Commons licence, and indicate if changes were made. The images or other third party material in this article are included in the article's Creative Commons licence, unless indicated otherwise in a credit line to the material. If material is not included in the article's Creative Commons licence and your intended use is not permitted by statutory regulation or exceeds the permitted use, you will need to obtain permission directly from the copyright holder. To view a copy of this licence, visit http://creativecommons.org/licenses/by/4.0/ The Creative Commons Public Domain Dedication waiver (http://creativecommons.org/publicdomain/zero/1.0/) applies to the data made available in this article, unless otherwise stated in a credit line to the data. 


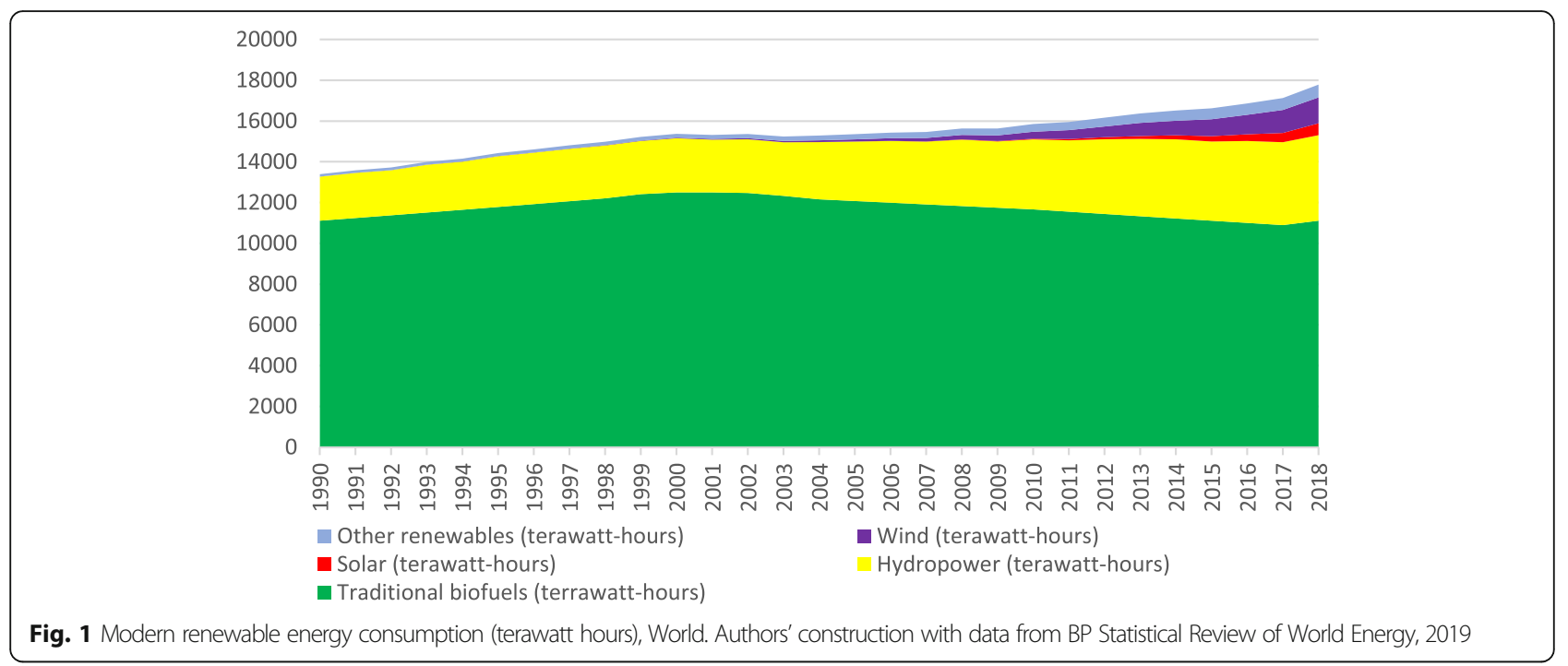

of percentage growth, wind and solar have seen a tremendous rise. Over the same period, hydroelectric and other sources have also grown by about $21 \%$ and $52 \%$, respectively. Again, from the year 2000 to 2018, wind and solar have risen substantially (237\%) while hydroelectric and other sources of renewable energy have increased relatively lesser (58\%). Since 2015, growth in world renewable energy consumption has mainly been from solar (about $124 \%$ ) and wind (about 53\%) compared with hydroelectricity (about $8 \%$ ) and other sources (about 16\%).

The demand for renewable energy consumption will rise markedly in developing countries. This follows the projection that by 2050 over $90 \%$ of the world's population growth will be in developing countries [3]. However, what is unknown and remains a key research question is whether economic well-being and economic freedom drives the share of renewables in total energy consumption in Africa. To address this, we commence by appreciating the current situation in Africa. From Fig. 2, there is evidence of a sharp rise in demand for modern renewable energy consumption in Africa. The case in Africa reveals that solar and wind has not been a source of renewable energy consumption before the millennium (i.e., 1990-1999). Instead, hydroelectric and other sources have been the core sources of renewable energy consumption. However, beyond the millennium (i.e., 20002018), growth in modern renewable energy consumption has been mainly by solar and wind. Similarly, from 2015 to 2018 , solar and wind have continued to dominate the growth of modern renewable energy consumption.

Promotion of modern renewable energy (such as biofuels, geothermal, wind, solar PV, hydropower,

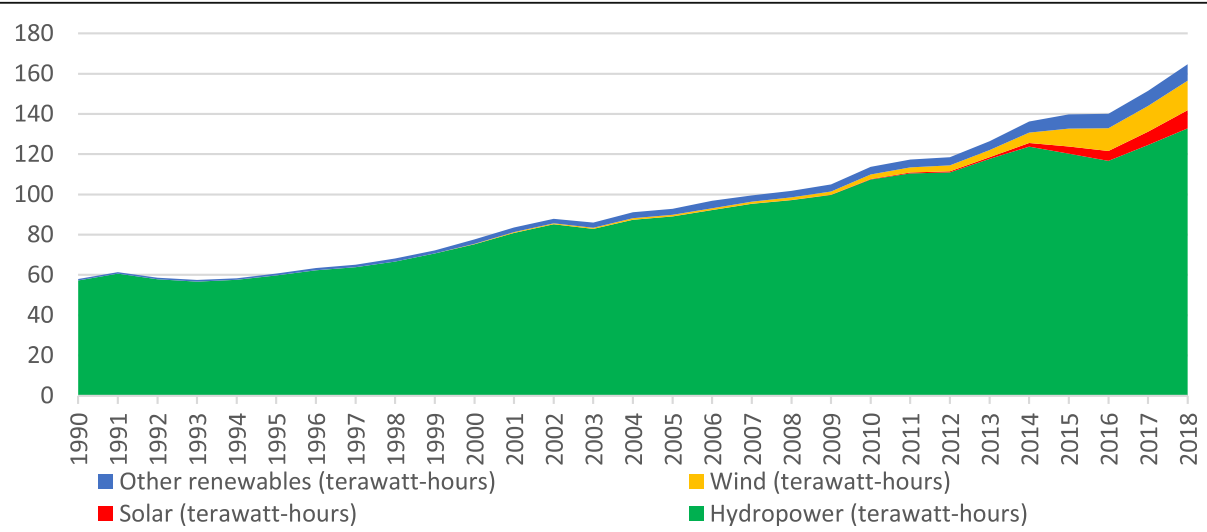

Fig. 2 Modern renewable energy consumption (terawatt hours), Africa. Authors' construction with data from BP Statistical Review of World Energy, 2019 
wave and tidal) has gained global support because it addresses issues that bother on greenhouse gases and uncertainties with energy crises associated with traditional sources of energy. Despite the benefits of energy security, sustainable growth, and environmental protection linked with the use of modern renewable energy, its share of total energy production and consumption in Africa is relatively low compared with the world average. Data from the world development indicators [4] for the period 1996 to 2018 (2016-2018 projected) shows that the average growth rate of global modern renewable energy production exceeds that of Africa by $8.43 \%$. This represents more than half of the production levels in the entire continent of Africa. Low levels of modern renewable energy production and use in Africa can be attributed to low average income levels, unfavorable market conditions, and inadequate technical ability to harness renewable energy. In developing countries such as those in Africa, market failure is a major reason why resources are not channeled efficiently toward harnessing renewable energy. Also, there are problems with weak institutions, unnecessary government interference, and inadequate incentives which lead to increases in implicit costs incurred in the form of administrative inefficiencies [5].

As regards the role of policy, we argue that from the 1980s until now, several countries in Africa have gone through different phases of the World Bank and IMF assisted economic and institutional reforms. For instance, the implementation of the economic recovery and structural adjustment programs between 1980 and early 1990s, as well as the millennium development goals (MDGs) and sustainable development goals (SDGs), has persuaded governments to consciously pursue strategic policies that have led to rising levels of per capita incomes and improvement in institutional quality on the continent. However, following the culmination of these events since the 1980 s, one would ask whether such economic and institutional reforms have contributed to renewable energy production and consumption in Africa.

This study seeks to find out whether economic wellbeing proxied by the human development index (HDI) and institutional quality proxied by economic freedom indices are determinants of the share of renewables in total energy consumption in Africa. Nonetheless, few studies have investigated parts of our interest. For example, there have been studies on renewable energy demand and economic growth $[6,7]$. To the best of our knowledge, we acknowledge that the most recent study that included HDI is Ergun et al. [8]. Although a recent study, endogeneity concerns were not addressed. Another point of departure is that apart from extending their period of study, we evaluate the effect of improvements in the standard of living (HDI) and disaggregated measures of economic freedom on the share of renewables in total energy consumption in Africa. Also, we extend the frontier of research by estimating the threshold effect of rising levels of HDI on the share of renewables in total energy consumption. The findings are to help policymakers redirect strategic reforms toward sustainable energy consumption in line with provisions of the SDGs. Practically, this study provides information for governments and policymakers on the need to prioritize human development and strengthen institutions to boost renewable energy consumption.

To achieve the core objectives, we use a panel data of 32 countries (see Appendix Table 14) over 22 years and estimate an econometric model using the dynamic ordinary least squares (DOLS) method. We use this method because of its adjustments with leads and lags. Thus, the estimator addresses identification issues bothering on endogeneity and serial correlation. For robustness purposes, we also estimate a fully modified ordinary least squares (FMOLS) and pooled ordinary least squares (POLS). The findings of the study provide evidence to support the theoretical expectation that economic wellbeing and economic freedom are drivers of the share of renewables in total energy consumption in Africa. Using HDI as a measure of economic well-being, we have evidence of a positive and statistically highly significant effect to a point after which it turns negative. The results for the disaggregated measures of economic freedom and renewable energy are mixed. In one breadth, property rights and tax burden decrease the share of renewables in total energy consumption. In contrast, an increase in trade freedom and business freedom increases the share of renewables in total energy consumption.

The remainder of the paper is structured as follows: The "Literature review" section reviews the literature. The "Methodology" section outlines the methodology. The "Results" section presents the results of the study. In the "Discussion" section, we discuss the results of the study, and conclude with policy implications in the "Conclusion" section.

\section{Literature review \\ Theoretical foundations}

In line with the basic consumption theory, just as a relationship exists between income and consumption, so does a relationship exists between income and the consumption of energy. This relationship may have influenced the pioneering work of Kraft and Kraft [9] who established a causal relationship between energy consumption and economic growth in the USA from 1947 to 1974. Since then, scores of studies [10, 11] have examined the energy-growth nexus using a variety of econometric techniques, covering different periods and samples with divergent results. Consistent 
with theoretical underpinnings, the results of such studies can be categorized into four key hypotheses:

\section{The neutrality hypothesis}

The neutrality hypothesis suggests that there is no relationship between economic growth and energy, and if any exist, it is weak at best. Thus, no causal relationship exists between energy and growth. An empirical study that has provided credence to support this hypothesis is Aïssa et al. [12].

\section{The growth hypothesis}

The growth hypothesis postulates that economic growth depends on energy. It means that there is a unidirectional causality running from energy to growth. This describes the case of an economy that relies on energy to propel economic growth. Thus, a limited supply of energy may constrain or hamper growth. Odhiambo [13] found unidirectional causality running from energy consumption to economic growth.

\section{The conservation hypothesis}

The conservation hypothesis implies that economic growth does not depend on energy. It suggests that there is a unidirectional causality running from growth to energy. Therefore, the economy relies less on energy to propel growth such that energy conservation policies can be carried out without any detrimental effect on growth. An example of a study that supports this hypothesis is Salim and Rafiq [14].

\section{The feedback hypothesis}

This indicates a bidirectional causality between energy and economic growth. The feedback hypothesis shows a strong complementarity between economic growth and energy. Apergis and Payne [15] have provided a piece of evidence to support this hypothesis.

\section{Empirical literature}

In this section, we acknowledge that there is a vast literature on the subject in question. For a better appreciation of the context, we group the empirical literature into developed and developing/emerging countries as well as on institutions.

\section{Developed countries}

Several studies have examined the drivers of renewable energy in developed countries [15-20]. For instance, Sadorsky [14] examined the determinants of renewable energy in G7 countries from 1980 to 2005 . By using an error correction model and seemingly unrelated regression, the author found that per capita GDP, per capita $\mathrm{CO}_{2}$ emissions, and oil prices are the main drivers of renewable energy consumption per capita.
Similarly, Apergis and Payne [18] examined the causal dynamics between renewable energy, per capita GDP, per capita $\mathrm{CO}_{2}$ emissions, and oil prices for 25 Organisation for Economic Co-operation and Development (OECD) countries from 1980 to 2011. The authors demonstrated that per capita GDP, per capita $\mathrm{CO}_{2}$ emission, and oil prices exert a positive and statistically significant effect on per capita renewable energy consumption in both the short and the long-run. Moreover, in both the short-run and the long-run, a bidirectional causality exists between the variables. These results corroborate with the earlier study of Sadorsky [16].

Whereas the earlier studies by Sadorsky [16] and Apergis and Payne $[15,18]$ found that per capita GDP, per capita $\mathrm{CO}_{2}$ emissions, and oil prices drive renewable energy consumption, other studies have found evidence to the contrary. For instance, Marques and Fuinhas [17] examined the determinants of renewable energy in 24 European countries from 1990 to 2006. Using a dynamic panel data model, the authors found that energy use per capita exerts a positive effect on renewable energy consumption while per capita $\mathrm{CO}_{2}$ emissions exert a negative effect on renewable energy consumption. However, per capita GDP, energy imports, and fossil fuel prices exert no significant effect on renewable energy consumption. Akar [20] also investigated the factors that drive renewable energy consumption in Balkan countries from 1997 to 2011. By using a dynamic panel model, the author revealed that natural gas rent and trade openness both promote renewable energy consumption, whereas economic growth reduces renewable energy consumption. However, per capita $\mathrm{CO}_{2}$ emissions and oil rents exert no significant effect on renewable energy consumption.

Mehrara et al. [19] examined factors that affect renewable energy consumption in the Economic Cooperation Organization (ECO) countries from 1992 to 2011. Using Bayesian model averaging and weighted-average least square techniques, the authors revealed that the key drivers of renewable energy consumption in ECO countries are human capital, urban population, institutional environment proxies, regulatory quality, and renewable potential. However, $\mathrm{CO}_{2}$ emission has a significant and negative effect on renewable energy consumption.

\section{Developing and emerging countries}

A plethora of studies has also examined the determinants of renewable energy consumption in developing and emerging countries $[14,21,22]$. For instance, Sadorsky [6] explored the effect of per capita GDP and the price of electricity on renewable energy consumption in 18 emerging countries from 1994 to 2003. Using a panel cointegration technique, the author found that a long-run relationship exists between 
per capita GDP and renewable energy consumption. In the short-run, there is no bidirectional causality between per capita income and renewable energy consumption.

In a related study, Salim and Rafiq [14] explored the factors that affect renewable energy adoption in six major emerging countries from 1980 to 2006. Using DOLS, FMOLS, and autoregressive distributed lags estimation techniques, the authors found that in Indonesia, India, China, and Brazil, per capita GDP and per capita $\mathrm{CO}_{2}$ emissions exert a positive and statistically significant effect on renewable energy consumption. However, only per capita GDP was positive and significant in the Philippines and Turkey. Besides, there was evidence of bidirectional causality between renewable energy consumption and per capita GDP in Turkey, China, Brazil, and the Philippines. Moreover, bidirectional causality between renewable energy consumption and per capita $\mathrm{CO}_{2}$ emission was found in Indonesia, India, China, and Brazil. The authors further revealed a bidirectional causality between per capita GDP and per capita $\mathrm{CO}_{2}$ emissions in China and Brazil, and unidirectional causality from per capita GDP to renewable energy consumption in Indonesia and India. Nevertheless, oil prices exert no statistically significant effect on renewable energy consumption.

Similarly, Apergis and Payne [15] investigated the effect of per capita GDP, per capita $\mathrm{CO}_{2}$ emissions, and fossil fuel prices on renewable energy consumption per capita in seven Central American countries from 1980 to 2010. By using the vector error correction model, the authors found a positive and statistically significant relationship between per capita GDP, per capita $\mathrm{CO}_{2}$ emissions, price of oil, price of coal, and per capita renewable energy consumption. In both the long-run and the short-run, there exists bidirectional causality between the variables. The results indicate that a $1 \%$ increase in per capita GDP, per capita $\mathrm{CO}_{2}$ emissions, prices of coal, and prices of oil propels per capita renewable energy use by $0.376 \%, 0.219 \%$, $0.153 \%$, and $0.285 \%$ respectively.

Pfeiffer and Mulder [21] also examined the factors that affect renewable energy technology diffusion in 108 developing countries from 1980 to 2010 using two-part and two-step selection models. The authors showed that per capita GDP, education, regulatory tools, and economic incentives exert a positive and statistically significant effect on per capita electricity produced from renewables. However, trade openness, foreign direct investment, increase in electricity consumption, and power generated from fossil fuels exert a negative and statistically significant effect, while financial development and Kyoto protocol exert no significant effect.

Omri et al. [22] also investigated the drivers of renewable energy consumption for a sample of 64 countries categorized into high, middle and low-income countries from 1990 to 2011. Using static and dynamic panel data techniques, the authors revealed that per capita GDP and per capita $\mathrm{CO}_{2}$ emissions significantly drive renewable energy consumption. Trade openness also exerts a positive effect on renewable energy consumption except for high-income countries. In the full sample, crude oil price exerts a positive and significant effect on renewable energy consumption.

In Africa, Ouedraogo [7] studied the relationship between access to modern energy, economic growth, and development for ECOWAS countries from 1980 to 2008. By using FMOLS estimation technique, the author showed that, in the short-run, economic growth exerts a positive and statistically significant effect on modern energy consumption in ECOWAS. The study showed that when real GDP increases, it affects modern energy demand in several ways: First, at the household level, with the rise in per capita income, individuals seeking to improve their comfort spend extra income on additional modern energy services. Moreover, since energy is essential in the production process, economic growth can trigger the demand for additional modern energy. Thus, an increase in real GDP increases modern energy consumption in the short-run increasing production in the real sector. Conversely, in the long-run, it is modern energy consumption which causes the GDP per capita growth in the ECOWAS.

Aissa et al. [12] explored the link between renewable consumption, output, and trade for a panel of 11 African countries spanning 1980 to 2008. In their short-run findings, no causality was found between output and renewable energy consumption as well as between trade and renewable energy consumption. In the long-run, there is no causality from output or trade to renewable energy consumption. Also, renewable energy consumption and trade have a positive and statistically significant effect on output.

Using a panel of 22 countries drawn from Africa, Attiaoui et al. [23] also examined the effect of per capita GDP, per capita $\mathrm{CO}_{2}$ emissions, per capita nonrenewable energy consumption on per capita renewable energy consumption from 1990 to 2011. By using an autoregressive distributed lag (Pooled Mean Group) model, the authors revealed that per capita GDP exerts no significant effect on renewable energy consumption. Per capita $\mathrm{CO}_{2}$ emissions exert a negative effect and non-renewable energy per capita exerts a positive effect on renewable energy consumption.

Another panel study by Ackah and Kizys [24] analyzed factors that affect renewable energy demand in oilproducing African countries from 1985 to 2010. Using both static and dynamic panel models, the authors found that per capita energy resource, per capita GDP, per 
capita capital stock, and population increase renewable energy consumption. However, per capita $\mathrm{CO}_{2}$ emissions and energy prices reduce per capita energy consumption while human capital exerts no significant effect. Employing an autoregressive distributed lags panel model, da Silva et al. [25] also examined the factors that affect renewable energy growth in Sub-Saharan Africa from 1990 to 2014. The authors found that real income per capita and energy use per capita exert a positive and significant effect on renewable energy use. However, energy prices, population, per capita $\mathrm{CO}_{2}$ emissions, electricity import, and Kyoto protocol ratification exert a negative effect on renewable energy consumption. The findings of da Silva et al. [25] corroborates with the findings of Ackah and Kizys [24].

In a recent study, Ergun et al. [8] explored the effects of Human Development Index, per capita GDP, foreign direct investment, democracy on the share of renewable energy in total energy consumption for a panel of 21 African countries from 1990 to 2013. Using the random effects generalized least squares, the authors revealed that countries with higher gross domestic product per capita and higher HDI have a lower share of renewable energy in total energy consumption. In contrast, an increase in foreign direct investment drives higher renewable energy consumption. In addition, democracy proxied by political rights and civil liberties ratings do not directly drive renewable energy consumption. The negative relationship between per capita GDP and the share of renewable energy in total energy consumption contradicts the previous findings of Ackah and Kizys [24] and da Silva et al. [25].

To the best of our knowledge, the most recent study that included HDI is by Ergun et al. [8] as earlier mentioned. However, they did not adequately address identification issues. Also, they used a relatively smaller cross section. To build on this, the present study examines the effect of HDI and disaggregated economic freedom measures on the share of renewables in total energy consumption in Africa. Likewise, we estimate the turning point that was not considered by Ergun et al. [8].

\section{Institutions and renewable energy consumption}

In this section, we review the relevant literature on economic freedom as a measure of institutional quality in promoting renewable energy consumption. Economic freedom refers to the role played by market institutions in creating an incentive structure within which economic agents function, leading to efficient resource allocation. Gwartney and Lawson [26, 27] indicated that robust institutional arrangements could prevent market failure and spur growth.

Similarly, Marinescu and Fucec [28] used economic freedom as a measure of institutional quality to examine the impact of economic freedom on the efficiency of renewable energy investments and inflows for five European countries. Using panel data spanning the period 1995 to 2011, and employing two linear regression models, the study indicated that economic freedom positively affects renewable energy investments in Germany and Greece. Within the same period, the number of investments increased with an increase in economic freedom. The authors found that economic freedom represents a positive determinant for the efficiency of investments in renewable energy for Switzerland, Romania, and Ukraine.

Wu and Broadstock [29] also investigated the effect of financial development and institutional quality on renewable energy infrastructure for a panel of 22 emerging countries over the period 1990 to 2010. The authors found that financial development and institutional quality exert a positive impact on renewable energy consumption.

Lastly, Bhattacharya et al. [30] investigated the relationship between renewable energy consumption, institutions, and carbon dioxide emissions using annual data for 85 developed and developing countries from 1991 to 2012. Results based on system-GMM and FMOLS suggest that institutional alignment is necessary to promote the consumption of renewable energy across economic activities to guarantee sustainable economic growth.

From the review, it is evident that institutions and well-being drive renewable energy consumption. In light with our review, no study has used both disaggregated economic freedom and HDI in a panel study for renewable energy in Africa. By this study, we fill the gap.

\section{Conceptual framework}

This section specifies a profit maximization function for renewable energy following the study of AmuakwaMensah et al. [31]. The theoretical model specification is the profit maximization objective of a firm. Firms seek to maximize profit by choosing the optimal level of input, which includes renewable energy input, subject to a given level of technology. Thus, by assuming a CobbDouglas production function, the firm maximizes profit (as shown in Eq. 1) subject to the production technology (shown in Eq. 2).

$$
\operatorname{Max} \rightarrow \pi=P Q-P_{Z} Z-P_{X} X \quad \text { [Profit function] }
$$

Subject to : $Q=A Z^{\alpha} X^{\beta}$ [Production technology]

where $\Pi, P, Q, Z, X, P_{Z}$, and $P_{X}$, are firm's profit, output price (the general price level), economic-wide output, renewable energy demand, composite input (demand for all other inputs), price of renewable energy input, and price of composite input (Note: price is normalized to one, i.e., $\left.P_{X}=1\right)$, respectively. Likewise, $A$ is the level of 
knowledge accumulation (total factor productivity), and $\alpha$ and $\beta$ indicate the respective share of renewable energy input and composite input in total production or elasticities. To solve the optimization problem, the Lagrangian equation (see Eq. 3) is differentiated with respect to renewable energy demand $(Z)$, composite input $(X)$, and the Lagrangian multiplier $(\lambda)$.

$$
L=P Q-P_{Z} Z-X+\lambda\left[Q-A Z^{\alpha} X^{\beta}\right]
$$

The first-order conditions for maximization are the following:

$$
\begin{aligned}
& \frac{\partial L}{\partial Z}=-P_{Z}-\lambda \alpha A Z^{\alpha-1} X^{\beta}=0 \\
& \frac{\partial L}{\partial X}=-1-\lambda \beta A Z^{\alpha} X^{\beta-1}=0 \\
& \frac{\partial L}{\partial \lambda}=Q-A Z^{\alpha} X^{\beta}=0
\end{aligned}
$$

Simultaneous solutions for Eqs. 4 to 6 give the optimal demand for renewable energy and composite inputs required for the firm's optimal profit, given technology. We focus on the optimal renewable energy input requirement in this study, which is given as:

$$
Z=\left(\frac{\alpha}{\beta}\right)^{\beta}\left(\frac{1}{P_{Z}}\right)^{\beta}\left(\frac{Q}{A}\right)
$$

Equation 7 shows the firm's optimal demand for renewable energy, assuming a perfectly competitive market environment. This renewable energy demand function is inversely proportional to technology and its price, and increases in output.

In order to introduce our variables of interest, we make the total factor productivity $(A)$ the subject and rewrite Eq. 7 as follows:

$$
\begin{aligned}
& A=\left(\frac{Q}{Z}\right)\left(\frac{1}{P_{Z}}\right)^{\beta}\left(\frac{\alpha}{\beta}\right)^{\beta} \\
& \ln A=\ln \left(\frac{Q}{Z}\right)+\beta \ln \left(\frac{1}{P_{Z}}\right)+\beta \ln \left(\frac{\alpha}{\beta}\right) \\
& e^{\ln A}=e^{\left(\ln \left(\frac{Q}{Z}\right)+\beta \ln \left(\frac{1}{P_{Z}}\right)+\beta \ln \left(\frac{\alpha}{\beta}\right)\right)}
\end{aligned}
$$

As shown in Eq. 8, " $A$ " can be expressed as a positive exponential function of human development (HDI), economic structure (ES), and economic freedom which is disaggregated into property rights (PR), business freedom (BF), trade freedom (TF), and tax burden (TB). This expression is conceivable given that HDI, economic structure, and economic freedom drive total factor productivity through access and affordability of new technology and innovation. This is consistent with the endogenous growth theory. The total factor productivity stemming from HDI, economic freedom, etc., is rooted in human capital (e.g., stock of ideas, wealth, health), better government, and factor market institutions.

$$
A=e^{\left(\beta_{2} H D I+\beta_{3} H D I^{2}+\beta_{4} P R+\beta_{5} B F+\beta_{6} T F+\beta_{7} T B+\beta_{8} E S\right)}
$$

By replacing the expression for " $A$ " in Eq. 7 with Eq. 8, the renewable energy function changes to Eq. 9. Thus, renewable energy $(Z)$, as shown in Eq. 9, is a function of price of renewable energy, output, human development, property rights, business freedom, trade freedom, tax burden, and economic structure.

$$
Z=\left(\frac{\alpha}{\beta}\right)^{\beta}\left(\frac{1}{P_{Z}}\right)^{\beta}\left(\frac{Q}{e^{\beta_{2} H D I+\beta_{3} H D I^{2}+\beta_{4} P R+\beta_{5} B F+\beta_{6} T F+\beta_{7} T B+\beta_{8} E S}}\right)
$$

Finding the natural $\log$ of both sides of Eq. 9 yields:

$$
\begin{aligned}
\ln Z= & \beta \ln \left(\frac{\alpha}{\beta}\right)-\beta \ln P_{Z}+\operatorname{In} Q-\left(\beta_{2} H D I+\beta_{3} H D I^{2}+\beta_{4} P R\right. \\
& \left.+\beta_{5} B F+\beta_{6} T F+\beta_{7} T B+\beta_{8} E S\right)
\end{aligned}
$$

In Eq. (10), $Q$ and HDI are expected to be correlated. To avoid multicollinearity, we dropped $Q$ from the final model. Also, given the paucity of data on prices of renewable energy on specific countries within Africa, we rewrite Eq. (10) as Eq. (11), focusing on HDI and economic freedom measures. Hence $\delta_{1}, \delta_{2}, \delta_{3}, \delta_{4}, \delta_{5}, \delta_{6}$, and $\delta_{7}$ are the coefficients of human development, square of human development, property rights, business freedom, trade freedom, tax burden, and economic structure, respectively.

$$
\begin{aligned}
\ln Z= & \delta_{0}+\delta_{1} H D I+\delta_{2} H D I^{2}+\delta_{3} P R+\delta_{4} B F \\
& +\delta_{5} T F+\delta_{6} T B+\beta_{7} E S
\end{aligned}
$$

\section{Methodology}

The data used for the study are sourced from the Heritage Foundation [32] and the world development indicators (WDI) of the World Bank [4]. In this study, renewable energy consumption is defined as the share of renewable energy in total final energy consumption. Likewise, the variable of interest, HDI is defined as the average achievement of a country under three main dimensions namely: access to knowledge (education), long and healthy life (life expectancy), and a decent standard of living (per capita income). The HDI has a minimum value of zero and a maximum value of one. Countries are ranked as low human development (less than 0.550), medium human development (0.550-0.699), high human development (0.700-0.799), and very high human development ( 0.800 and above). Based on the average HDI values (see Table 1), indeed, Africa is ranked low 
Table 1 Descriptive statistics of variables

\begin{tabular}{|c|c|c|c|c|c|c|c|c|c|c|}
\hline Stats & $\begin{array}{l}\text { Renewable } \\
\text { energy }\end{array}$ & $\begin{array}{l}\text { Renewable } \\
\text { energy (log) }\end{array}$ & Property rights & Tax burden & $\begin{array}{l}\text { Business } \\
\text { freedom }\end{array}$ & $\begin{array}{l}\text { Trade } \\
\text { freedom }\end{array}$ & $\begin{array}{l}\text { Economic } \\
\text { structure }\end{array}$ & $\mathrm{HDI}$ & $\mathrm{HDI}^{\dagger}$ & $\begin{array}{l}\mathrm{HDI}^{\dagger} \\
\text { squared }\end{array}$ \\
\hline$\overline{\text { Mean }}$ & 65.33 & 4.18 & 35.85 & 70.28 & 56.05 & 59.28 & 0.64 & 0.49 & 49 & 2401 \\
\hline Median & 78.35 & 4.36 & 30.00 & 71.45 & 55.00 & 61.10 & 0.47 & 0.46 & 46 & 2116 \\
\hline SD & 28.99 & 1.15 & 14.81 & 10.66 & 11.74 & 13.78 & 0.50 & 0.11 & 0.11 & 0.11 \\
\hline Skewness & -0.95 & -3.21 & 0.36 & -0.65 & 0.10 & -0.85 & 2.05 & 0.39 & 0.39 & 0.39 \\
\hline Kurtosis & 2.53 & 14.75 & 2.94 & 3.17 & 2.90 & 3.59 & 6.66 & 2.36 & 2.36 & 2.36 \\
\hline Minimum & 0.06 & -2.83 & 5.00 & 32.80 & 23.40 & 16.20 & 0.05 & 0.25 & 25 & 625 \\
\hline Maximum & 98.34 & 4.59 & 75.00 & 90.80 & 85.00 & 89.00 & 2.75 & 0.75 & 75 & 5625 \\
\hline N & 704.00 & 704.00 & 704.00 & 704.00 & 704.00 & 704.00 & 704.00 & 704.00 & 704.00 & 704.00 \\
\hline
\end{tabular}

$S D$ standard deviation, $N$ number of observations, $\mathrm{HDI}^{+}$rescaled $\mathrm{HDI}$ values into percentages

Two decimal places are used in all cases where applicable

regarding human development. In order to interpret the HDI and its squared term as elasticities, it was re-scaled into percentages.

The economic freedom index measures the degree of economic freedom on a scale of 0 to 100. The old method had ten measures while the new method has twelve measures. These have been categorized under four broad headings regardless of the technique. These are the rule of law (property rights), the regulatory efficiency (business freedom), the open market (trade freedom), and the limited government or government control (tax burden). The study selected measures that represent the various four categories based on the principal component analysis with the largest eigenvalue (see Appendix Tables 5-12) and data availability. Two of the twelve measures were not used because they had some missing data points for the selected countries over the period under study. They include judicial effectiveness and fiscal health.

We admit that economic well-being and economic freedom measures are not the only drivers of renewable energy consumption in Africa. Other variables explained in the literature may include urbanization, economic structure, population, emissions $\left(\mathrm{CO}_{2}\right)$, foreign direct investment, financial market development among others. Given the evidence of multicollinearity and statistically superfluous explanatory variables, we included only the economic structure which seeks to capture the effect of possible structural changes in Africa. Following Mensah et al. [33], the economic structure is constructed as a ratio of industry valueadded to service value added. A priori, we expect a rise/decrease in the ratio to decrease/increase the share of renewables in total energy consumption.

Toward examining the properties of all the variables used in this study, we present the descriptive statistics of each of the variables used for the estimation. Details of variables, expected signs, descriptions, and sources have been captured in Appendix Table 13.

The dependent variable, which is defined as the share of renewables in total energy consumption, has a wide range, so it became necessary to transform it into natural logs. Now, the mean is quite close to the median with an associated standard deviation which is approximately equal to one while the range is relatively smaller. Next, the following variables property rights $[\mathrm{PR}]$, tax burden $[\mathrm{TB}]$, business freedom [BF], trade freedom [TF], and HDI have skewness and kurtosis of almost zero and three respectively. That is, except economic structure $[E S]$, most of the independent variables have nearnormal distributions. Given that the economic freedom values range from $0-100$, we ignored any transformation unlike the dependent variable and the HDI. We acknowledge that the transformations did not affect the total number of observations as well as the estimated results. These transformations can help us interpret the results as elasticities. Besides, we investigated the extent to which our variables are correlated and presented the results in Appendix Table 15. The variables TF and TB have the highest correlation coefficient of 0.5596. We argue in line with Amoah et al. [34] that the degree of collinearity is not so severe to inflate our estimates.

\section{Stationarity and panel cointegration tests}

Before the estimation, unit root properties of the series are investigated to verify whether they are stationary. This helps avoid possible spurious regression when dealing with the panel time-series dataset. In the literature, several methods have been proposed for investigating the unit root properties of variables used in panel time series modeling. In this study, for robustness purposes, tests that either assume individual unit root processes such as Augmented DickeyFuller, (ADF), Phillips-Perron (PP), and Im, Pesaran 
and Shin (IPS), or assumes common unit root processes such as Levin, Lin, and Chu (LLC) are used. In all, four-panel unit root approaches are used to test for the existence of unit root properties in the series. The test results are presented in Table 2 .

Regarding Table 2, following the LLC test with common unit root processes assumption, there is evidence that all the series are stationary at levels except BF. Nevertheless, under the same assumption, all the series are found to be stationary at first difference. Hence, there is a basis to infer from the LLC test that the panel time series variables are stationary at I(1). Additionally, concerning the individual unit root processes assumption, all the three tests, namely ADF, PP, and IPS, provide evidence in support of the LLC test that all the panel time series are I(1) variables. This implies that for a uniform conclusion of all the tests, there is evidence of stationarity after first differencing. Based on the unitroots tests, it can be reasoned that a standard POLS would not be an appropriate technique for estimation. Therefore, the study employs the DOLS method as developed by Kao and Chiang [35, 36] while the FMOLS and the POLS are used for robustness checks.

Before proceeding with estimation, it is also prudent to investigate the long-run relationship between the share of renewables in total energy consumption and the covariates. The model for the cointegration test following standard specification is shown in Eq. (12):

$$
\begin{aligned}
\ln Y_{i t}= & \beta_{i}+\gamma_{i} t+\alpha_{1 i} \mathrm{HDI}_{i t}+\alpha_{2, i} \mathbf{E F}_{i t} \\
& +\alpha_{3, i} \mathrm{ES}_{i t}+\varepsilon_{i t}
\end{aligned}
$$

where $\beta_{i}$ and $\gamma_{i}$ are country-specific effects and deterministic time trends, respectively; cross-sectional units, $i=1, \ldots \ldots ., N ; t$ refers to the time period, $t=1, \ldots \ldots, T$; $\varepsilon$ is the residual. $\mathrm{EF}$ is a vector of the measures of economic freedom and ES is a measure of the economic structure as earlier defined. All other variables are already defined.

The test for the long-run relationship specified as Eq. (12) is achieved using the panel cointegration approach as developed by Pedroni [37]. One strength of this approach is that it allows for heterogeneous intercepts and trend coefficients across cross sections which is an improvement over traditional approaches commonly found in the literature. The various statistics for this test are either based on the within approach (panel $v$-statistic, panel $\rho$-statistic, panel PP-statistic, panel ADF-statistic), or between approach (group rho-statistic, group PPstatistic, and group ADF-statistic). In addition to Pedroni's panel co-integration approach, we also used the Kao residual cointegration test and the standard Johansen Fisher panel cointegration test. Thus, the study combines both parametric and non-parametric tests for the purposes of testing for the long-run relationship.

Three unique test results are presented in Table 3. There is evidence to reject the null hypothesis of no

\begin{tabular}{|c|c|c|c|c|c|c|c|c|}
\hline Test methods & Variables & InRE & $\mathrm{HDI}$ & PR & $\mathrm{BF}$ & TF & TB & ES \\
\hline \multicolumn{9}{|c|}{ Null: Unit root (assumes common unit root process) } \\
\hline \multirow[t]{4}{*}{ LLC $_{\text {t-stat }}$} & Level & -2.17 & -5.60 & -2.91 & -0.21 & -4.97 & -3.15 & -4.47 \\
\hline & Prob. & 0.02 & 0.00 & 0.00 & 0.58 & 0.00 & 0.00 & 0.00 \\
\hline & 1. diff. & -10.99 & -4.58 & -1.73 & -8.07 & -11.45 & -10.87 & -19.69 \\
\hline & Prob. & 0.00 & 0.00 & 0.04 & 0.00 & 0.00 & 0.00 & 0.00 \\
\hline \multicolumn{9}{|c|}{ Null: Unit root (Assumes Individual unit root process) } \\
\hline \multirow[t]{4}{*}{$\mathrm{ADF}_{\text {Fisher chi-square }}$} & Level & 49.97 & 57.2 & 233.17 & 60.1 & 104.6 & 85.27 & 77.50 \\
\hline & Prob. & 0.90 & 0.71 & 0.00 & 0.61 & 0.00 & 0.04 & 0.00 \\
\hline & 1. diff. & 249.50 & 124.0 & 240.38 & 226.7 & 317.2 & 261.28 & 368.79 \\
\hline & Prob. & 0.00 & 0.00 & 0.00 & 0.00 & 0.00 & 0.00 & 0.00 \\
\hline \multirow[t]{4}{*}{$\mathrm{PP}_{\text {Fisher chi-square }}$} & Level & 53.85 & 87.57 & 64.81 & 76.94 & 112.56 & 101.03 & 95.53 \\
\hline & Prob. & 0.81 & 0.00 & 0.11 & 0.13 & 0.00 & 0.00 & 0.09 \\
\hline & 1. diff. & 493.57 & 267.6 & 269.33 & 646.6 & 1034.6 & 1102.7 & 413.49 \\
\hline & Prob. & 0.00 & 0.00 & 0.00 & 0.00 & 0.00 & 0.00 & 0.00 \\
\hline \multirow[t]{4}{*}{$\mathrm{IPS}_{\mathrm{w} \text {-stat }}$} & Level & 0.89 & 3.66 & -4.87 & -0.17 & -3.09 & -0.79 & -1.83 \\
\hline & Prob. & 0.81 & 0.00 & 0.00 & 0.43 & 0.00 & 0.21 & 0.03 \\
\hline & 1. diff. & -11.31 & -4.76 & -9.23 & -10.33 & -14.39 & -11.97 & -17.51 \\
\hline & Prob. & 0.00 & 0.00 & 0.00 & 0.00 & 0.00 & 0.00 & 0.00 \\
\hline
\end{tabular}

Table 2 Panel unit root test results 
Table 3 Panel cointegration test results

\begin{tabular}{|c|c|c|c|c|}
\hline \multicolumn{5}{|c|}{ 1. Pedroni's cointegration test (deterministic intercept and trend) } \\
\hline \multicolumn{5}{|c|}{ Common autoregressive coefficients (within dimension) } \\
\hline Tests & Statistic & $p$ value & Weighted statistic & $p$ value \\
\hline Panel $v$ statistic & -3.336065 & 0.9996 & -4.537104 & 1.0000 \\
\hline Panel rho statistic & 1.851068 & 0.9679 & 1.759351 & 0.9607 \\
\hline Panel PP statistic & -17.26343 & 0.0000 & -17.92932 & 0.0000 \\
\hline Panel ADF statistic & -7.347244 & 0.0000 & -7.065955 & 0.0000 \\
\hline \multicolumn{5}{|c|}{ Individual Autoregressive coefficients (between dimension) } \\
\hline Group rho statistic & 3.713946 & 0.9999 & & \\
\hline Group PP statistic & -32.93876 & 0.0000 & & \\
\hline Group ADF statistic & -8.285983 & 0.0000 & & \\
\hline \multicolumn{5}{|c|}{$\begin{array}{l}\text { 2. Kao residual cointegration test (no deterministic trend) } \\
\boldsymbol{H}_{0} \text {, no cointegration; } \boldsymbol{H}_{1} \text {, cointegration } \\
\text { Test statistic, } \boldsymbol{p} \text { value } \\
-20.13701^{* * *}, 0.0000 \\
\text { Note: Decision: Reject the null hypothesis and accept the alternative of cointegration }\end{array}$} \\
\hline \multicolumn{5}{|c|}{ 3. Johansen Fisher panel cointegration test (linear deterministic trend) } \\
\hline Null hypothesis & Fisher statistic (trace test) & $p$ value & $\begin{array}{l}\text { Fisher statistic } \\
\text { (maximum eigenvalue) }\end{array}$ & $p$ value \\
\hline$r=0$ & 47.53 & 0.3308 & 47.53 & 0.3308 \\
\hline$r \leq 1$ & 200.8 & 0.0000 & 2651 & 0.0000 \\
\hline$r \leq 2$ & 996.3 & 0.0000 & 4747 & 0.0000 \\
\hline$r \leq 3$ & 575.2 & 0.0000 & 375.0 & 0.0000 \\
\hline$r \leq 4$ & 291.1 & 0.0000 & 176.9 & 0.0000 \\
\hline$r \leq 5$ & 165.1 & 0.0000 & 115.0 & 0.0000 \\
\hline$r \leq 6$ & 146.0 & 0.0000 & 146.0 & 0.0000 \\
\hline
\end{tabular}

Notes: cointegration test results were generated by Eviews 9

Null hypothesis, no cointegration

Automatic lag length selection based on SIC with lags from 0 to 2

Sample period is 1996-2017

cointegration among the series for most of the tests. Based on this evidence, the study concludes that a longrun relationship exists among the variables. Therefore, there is basis to proceed with the model estimations.

\section{Econometric strategy}

In this study, a panel data of 32 African countries spanning 1996 to 2017 is used. The panel structure is based on data availability vis-à-vis our variables of interest for the study. Several estimators have been used in literature for estimating a co-integration vector using panel data. This study applies three of such estimators namely pooled OLS estimators, FMOLS estimators, and DOLS estimators. The latter is used as the preferred estimator while the former (OLS and FMOLS) are used for robustness checks. It is worth mentioning that OLS may not be appropriate for studies of this nature except the regressors are strictly exogenous and the panel data is stationary at levels.

The FMOLS is a better estimator over the OLS because it is an asymptotically efficient panel cointegration estimator. Again, it is a non-parametric estimator that uses an instrumental variable approach to provide robust estimators even for models with cointegrated I(1) variables. Unlike the OLS, in small samples, FMOLS provides consistent estimates. Also, FMOLS is free of large size distortions in the presence of endogeneity in the regressors and heterogeneous dynamics [38].

The DOLS is also an asymptotically efficient panel cointegration estimator [39]. Unlike the FMOLS, the DOLS applies a parametric adjustment to the errors by modifying the static regression with leads and lags. This helps in addressing issues of endogeneity and serial correlation commonly associated with panel time-series data. Also, according to Funk [40], p. 729 "the DOLS has better finite properties in terms of the bias in both the parameter estimates and the standard errors, the inclination is to accept the DOLS results over the FMOLS results". Given the strengths of the DOLS over both FMOLS and POLS, we agree with Kao and Chiang [36] to conclude that DOLS does not only perform better 
than FMOLS in parameter estimation and inference testing, it has also been adjudged superior. Hence, we used the DOLS as our preferred estimator.

The study proceeds by presenting a standard panel econometric model that explains the extent to which economic well-being and economic freedom explains changes in share of renewables in total energy consumption. Based on the standard POLS estimator, this is presented as:

$$
Y_{\mathrm{i}, \mathrm{t}}=\alpha_{i}+\boldsymbol{X}_{i, t} \beta+\varepsilon_{i, t}
$$

where the dependent variable $Y$ is the share of renewables in total final energy consumption in country $i$ at time $t$. The independent variable $X$ is the m-dimensional vector of the series of the data which are integrated of order one. The parameters of the regressors to be estimated are represented by $\beta$. The residuals $(\varepsilon)$ are assumed to be stationary and normally distributed at zero mean and a constant variance, $N\left(0, \sigma^{2}\right)$. The subscripts are as earlier defined. We re-write $\boldsymbol{X}$ to take a dynamic functional form as:

$$
X_{i, t}=X_{i, t-1}+v_{i, t}
$$

In line with Funk [40] and Korle et al. [41], Eq. (13) can be re-specified as a panel DOLS estimator to incorporate the lags and leads. This can be represented as:

$$
Y_{i, t}=\gamma_{i}+\boldsymbol{X}_{i, t} \beta+\sum_{j=-p_{1}}^{p_{2}} c_{i, j} \Delta_{i, t+j}+u_{i, t}
$$

Based on Eq. 14, the FMOLS estimator is represented as:

$$
\hat{\beta}_{F M O L S}=\left[\sum_{i=1}^{N} \sum_{t=1}^{T}\left(X_{i, t}-\bar{X}_{i}\right)\left(X_{i, t}-\bar{X}_{i}\right)^{\prime}\right]^{-1}\left\{\sum_{t=1}^{N}\left[\sum_{t=1}^{T}\left(X_{i, t}-\bar{X}_{i}\right) \hat{Y}_{i, t}^{+}-T \hat{\Delta}_{c, u}^{+}\right]\right\}
$$

where the serial correlation and the endogeneity correction terms are represented as $\hat{\Delta}_{\epsilon, u}^{+}$and $\hat{Y}_{i, t}^{+}$respectively. Next, the preferred DOLS estimator follows as:

$$
\beta_{D O L S}^{*}=N^{-1} \sum_{i=1}^{N}\left(\sum_{t=1}^{T} X_{i, t} X_{i, t}^{i}\right)^{-1}\left(\sum_{t=1}^{T} X_{i, t} Y_{i, t}^{*}\right)
$$

From the DOLS estimator captured in Eq. 16, $X_{i, t}$ represents a $2(\mathrm{~K}+1) 1$ vector of independent variables used in the estimation. Now, the general final model for estimation is shown that the share of renewables in total energy consumption as a function of economic well-being, economic freedom, and economic structure. This is simplified as:

$$
Y=f(\mathrm{HDI}, \mathrm{EF}, \mathrm{ES})
$$

Given that the economic freedom is disaggregated, Eq. (17) is re-written in a more explicit form as:

$$
\begin{aligned}
\mathbf{Y}_{\mathbf{i}, \mathrm{t}}= & \beta_{0}+\beta_{1} H D I_{i, t}+\beta_{2} \mathbf{H D I}_{i, t}^{2}+\beta_{3} \mathbf{P R}_{i, t} \\
& +\beta_{4} \mathbf{B F}_{i, t}+\beta_{5} \mathbf{T F}_{i, t}+\beta_{6} \mathbf{T B}_{i, t}+\beta_{7} \mathbf{E S}_{i, t} \\
& +\varepsilon_{i, t}
\end{aligned}
$$

From Eq. (18), all variables are as earlier defined. This equation is estimated, and the results are presented in Table 4.

\section{Results}

Table 4 shows three estimated models: Models 1 (POLS) and 2 (FMOLS), respectively, are used for robustness checks. As already justified, we use model 3 (DOLS) as our preferred model. From the theoretical and empirical evidence, one would expect a positive relationship between economic well-being, economic freedom, and the share of renewables in total energy consumption. This is plausible in that a country with strong institutions, economic power, educated people who are conscious of their health, and the consequences of using non-renewable sources of energy are more likely to use renewable energy sources.

As earlier acknowledged, we used HDI as a measure of economic well-being. The study found that HDI exerts a positive and statistically significant effect on the share of renewables in total energy consumption at $1 \%$ level in Africa. That is, a percentage point rise in HDI is associated with a 5.54 percentage point rise in the share of renewables in total energy consumption in Africa. By implication, as African countries move on the HDI scale from zero upwards (i.e., relatively high levels of HDI), the share of renewables in total energy consumption increases. It means that consistent with theory, an increase in economic wellbeing increases the share of renewables in total energy consumption. Zhao and Luo [42] and Sadorsky [6] are some of the developing country studies with similar findings.

The coefficient of the quadratic term of HDI is negative and highly significant statistically at $1 \%$ level. This implies that a percentage point rise in the squared term of HDI decreases the share of renewables in total energy consumption by about 0.07 percentage point. This shows evidence of an inverted $\mathrm{U}$ shape, suggesting the absence of a second-order positive effect. By implication, a further rise in economic well-being by double reduces the share of renewables in total energy consumption but at a decreasing rate. This finding is intuitively in line with evidence by Ben Jebli et al. [43]. The turning point is estimated to 
Table 4 DOLS regression results

\begin{tabular}{|c|c|c|c|}
\hline \multirow[t]{2}{*}{ Variables } & (1) & $(2)$ & (3) \\
\hline & POLS & FMOLS & DOLS \\
\hline \multicolumn{4}{|l|}{ Economic well-being } \\
\hline \multicolumn{4}{|l|}{ Standard of living measure } \\
\hline \multirow[t]{2}{*}{$\mathrm{HDI}^{\dagger}$} & $0.0435^{* * *}$ & $0.0441^{* * *}$ & $0.0554^{* * *}$ \\
\hline & $(0.010)$ & $(0.002)$ & $(0.002)$ \\
\hline \multirow[t]{2}{*}{ c.HDI\#c.HDI (HDI_squared) ${ }^{\dagger}$} & $-0.0006^{* * *}$ & $-0.0006^{* * *}$ & $-0.0007^{* * *}$ \\
\hline & $(0.000)$ & $(0.000)$ & $(0.000)$ \\
\hline \multicolumn{4}{|l|}{ Economic freedom } \\
\hline \multicolumn{4}{|l|}{ Rule of law measures } \\
\hline \multirow[t]{2}{*}{ Property rights } & -0.0004 & $-0.0003^{*}$ & $-0.0006^{*}$ \\
\hline & $(0.001)$ & $(0.000)$ & $(0.000)$ \\
\hline \multicolumn{4}{|l|}{ Regulatory efficiency measures } \\
\hline \multirow[t]{2}{*}{ Business freedom } & 0.0002 & 0.0002 & $0.0009^{* * *}$ \\
\hline & $(0.001)$ & $(0.000)$ & $(0.000)$ \\
\hline \multicolumn{4}{|l|}{ Open market measures } \\
\hline \multirow[t]{2}{*}{ Trade freedom } & 0.0007 & $0.0007^{* * *}$ & $0.0010^{* * *}$ \\
\hline & $(0.001)$ & $(0.000)$ & $(0.000)$ \\
\hline \multicolumn{4}{|l|}{ Limited government measures } \\
\hline \multirow[t]{2}{*}{ Tax burden } & $-0.0043^{* * *}$ & $-0.0043^{* * *}$ & $-0.0062^{* * *}$ \\
\hline & $(0.001)$ & $(0.000)$ & $(0.000)$ \\
\hline \multicolumn{4}{|l|}{ Structural changes } \\
\hline \multirow[t]{2}{*}{ Economic structure } & $-0.0873^{* * *}$ & $-0.0879^{* * *}$ & $-0.1133^{* * *}$ \\
\hline & $(0.022)$ & $(0.011)$ & $(0.015)$ \\
\hline \multirow[t]{2}{*}{ Constant } & $-1.1887^{* * *}$ & $-1.1779 * * *$ & $-1.4550^{* * *}$ \\
\hline & $(0.264)$ & $(0.062)$ & $(0.093)$ \\
\hline Year dummies & Yes & Yes & Yes \\
\hline Country dummies & Yes & Yes & Yes \\
\hline Observations & 704 & 703 & 701 \\
\hline$R$-squared & 0.989 & 0.942 & 0.991 \\
\hline Turning point (n/com) & $0.73^{* * *}$ & $0.74^{* * *}$ & $0.79^{* * *}$ \\
\hline Std. error & $(0.46)$ & $(0.01)$ & $(0.11)$ \\
\hline
\end{tabular}

Dep variable: share of renewable energy in total energy consumption (In) Robust standard errors in parentheses for OLS model only

${ }^{* * *} p<0.01$

${ }^{* *} p<0.05$

${ }^{*} p<0.1$

be 0.79 . This is statistically highly significant at $1 \%$ level. It implies that as average HDI in Africa rises to a maximum of 0.79 , thereafter, the share of renewables in total energy consumption falls. The quadratic evidence found here, is consistent with the evidence in some studies that used per capita income such as Zhao and Luo [42].

A key determinant of renewable energy consumption is the role of regulatory institutions. Regarding the use of renewable energy, the quality of institutions in making laws and policies as well as enforcing the same is very crucial. In this study, we used economic freedom as a measure of institutional quality. Informed by the largest eigenvalue of the principal component analysis (PCA) in Appendix Tables 5 to 12 , the property right is selected as a measure of rule of law (see Appendix Tables 5 and 6). For regulatory efficiency, based on the PCA (see Appendix Tables 9 and 10), we selected business freedom, which exerts a positive effect on the share of renewables on total energy consumption. The results show that a rise in property rights decreases the share of renewables in total energy consumption.

Again, we represented open market measures with trade freedom (see Appendix Tables 11 and 12). Trade freedom also exerts a positive effect on the share of renewables in total energy consumption. This implies that trade freedom has the potential to promote the use of renewable energy contrary to the view that trade harms the environment in developing countries. Lastly, the role of a government, especially in Africa, is very important. The government can regulate the activities of firms in the production of renewable and non-renewable energies. Here, we determine the extent of government control using tax burden (see Appendix Tables 7 and 8). This exerts a negative and statistically significant effect on renewable energy consumption.

We accept that indices of economic well-being and economic freedom are not the only drivers of Africa's share of renewables in total final energy use. Other variables discussed in the literature may include, among others, urbanization, economic structure, population, emissions (CO2), foreign direct investment, growth of the financial market. For reasons of serial correlation and statistically irrelevant variable, only urbanization is included as an additional explanatory variable. As expected, we find that a rise in economic structure decreases the share of renewables in total energy consumption. That is, as the ratio of industry valueadded to service value added increases, the share of renewables in total energy consumption decreases.

\section{Discussion}

Africa is generally endowed with enormous resources needed for production and consumption of renewable energy. However, the ability to harness sustainable renewable sources of energy has been a major challenge coupled with the enormous detrimental effect of nonrenewable sources on health and the environment [44]. This challenge can be attributed to low average income levels, unfavorable market conditions, and low technical ability to harness renewable energy sources. However, in relation to our findings, the rising level of HDI in Africa is found to drive the share of renewables in total energy consumption up to a point after which it turns negative. 
Thus, initially; with relevant policy initiatives, increase in well-being, and purchasing power, consumers tend to switch toward the consumption of renewable energy. Interestingly, we found that beyond a certain threshold, the rising levels of HDI will be associated with a lower share of renewables in energy consumption. All else held constant, this finding is plausible if the increase in renewable energy demand is without a corresponding increase in production. Expectedly, this would put an upward pressure on price and consequently a fall in demand. To curtail this shortfall in supply, there is the need to engage in the production and maintenance of renewable energy plants to meet the growing demand without depending heavily on the external supply of inputs (e.g., solar and wind power equipment and tools). This is conceivable given that solar and wind power has dominated the growth of renewable energy consumption from 2015 to 2018.

On the role of institutions in promoting consumption of renewable energy in Africa, the study finds that institutional variables such as property rights and tax burden have a negative influence on the share of renewables in total energy consumption. This is intuitive because, in the view of Locke [45], Africa is generally characterized by high levels of unequal asset and property distribution (inequality), which adversely impact the security of property rights. Thus, a rise in property rights could amplify the degree of inequality and negatively hurt the share of renewables in energy consumption. Since our study did not test this intuitive justification, we call for further research into this relationship.

Likewise, the higher the incidence of tax on consumers of renewable energy, the less renewable energy would be consumed. Theoretically, a direct tax on real income reduces the disposable income of consumers and weakens their purchasing power. Also, indirect taxes can lead to a loss in both consumer and producer surpluses (deadweight loss) which serve as a disincentive for renewable energy development. Since renewable energy is likely to have elastic demand as a result of its relatively higher cost compared to traditional energy sources in Africa, an increase in prices through indirect taxes could reduce renewable energy use.

Business freedom and trade freedom which are measures of freer markets were found to improve the share of renewables in total energy consumption. Business freedom serves as an incentive for economic agents to utilize and allocate resources efficiently. Thus, a stable and predictable business environment could promote not only investment in renewable energy but its use as well. This means business freedom in a well-regulated environment will enhance renewable energy use. Trade freedom through the composition effect may accelerate the transformation of an agrarian economy into industrial and finally into the services sector that is relatively less associated with pollution. Marinescu and Fucec [28] also point to the fact that economic freedom promotes efficiency in renewable energy investments. Thus, unnecessary government interference in such freer markets on the continent could be counterproductive.

\section{Conclusion}

This study examined the role of economic well-being and disaggregated measures of economic freedom as drivers of the share of renewables in total energy consumption in Africa. Given the panel time-series nature of the dataset, the study investigated the stationarity and cointegration properties of the panel to establish a longrun relationship between economic well-being, economic freedom, and renewable energy consumption for 32 African countries from 1996 to 2017.

In order to deal with issues that border on endogeneity and serial correlation, DOLS was used to estimate the long-run relationship. Further, robustness checks were investigated using FMOLS and POLS. Evidence from all the models suggests that economic well-being, economic freedom is key drivers of the share of renewables in total energy consumption in Africa.

The results suggest that improving HDI on the continent of Africa increases the share of renewable energy in total energy consumption up to a point, after which it begins to decrease. Again, disaggregated measures of economic freedom show that property rights and tax burden components also decrease the share of renewables in total energy consumption. However, an increase in open market components such as business freedom and trade freedom do increase the share of renewables in total energy consumption. Thus, an increase in open market and regulatory efficiency measures increases the share of renewables in total energy consumption. We recommend that the continent should not lose sight in building strong institutions that seek to promote renewable energy consumption and reduce supply and use of nonrenewable sources of energy due to economic expansion and promotion of trade liberalization policies. Again, there is the need to remove socio-economic and political barriers to increase production and use of renewable energy. Specifically, providing tax incentives and flexibility in the business registration process, governments and their planning agencies, international organizations, private investors, and non-profit organizations who are involved in renewable energy activities must synergize for the development of renewable energies across countries on the continent.

In a nutshell, given that improvement in human development and strong institutional development are key drivers of the share of renewables in total energy consumption in Africa, governments are encouraged to promote these drivers in line with the SDGs. 


\section{Appendix}

Table 5 Rule of Law Principal Components Analysis/Correlation

\begin{tabular}{lllll}
\hline Component & Eigenvalue & Difference & Proportion & Cumulative \\
\hline Comp 1 & $\mathbf{1 . 5 6 2 6 4}$ & 1.12529 & 0.7813 & 0.7813 \\
Comp 2 & 0.437356 & & 0.2187 & 1.0000
\end{tabular}

Data on judicial effectiveness/freedom has been dropped for paucity of data No. obs $=704$, no. of components $=2$, trace $=2$, rho $=1$

Table 6 Rule of law principal components (eigenvectors)

\begin{tabular}{llll}
\hline Variable & Comp 1 & Comp 2 & Unexplained \\
\hline Property right & $\mathbf{0 . 7 0 7 1}$ & 0.7071 & 0.0000 \\
Government integrity & 0.7071 & -0.7071 & 0.0000 \\
\hline
\end{tabular}

Table 7 Government size principal components analysis/ correlation

\begin{tabular}{lllll}
\hline Component & Eigenvalue & Difference & Proportion & Cumulative \\
\hline Comp 1 & $\mathbf{1 . 0 3 1 8 2}$ & 0.0636387 & 0.5159 & 0.5159 \\
Comp 2 & 0.968181 & & 0.4841 & 1.0000 \\
\hline
\end{tabular}

Data on fiscal health has been dropped for paucity of data

No. obs $=704$, no. of components $=2$, trace $=2$, rho $=1$

Table 8 Government size principal components (eigenvectors)

\begin{tabular}{llll}
\hline Variable & Comp 1 & Comp 2 & Unexplained \\
\hline Tax burden & $-\mathbf{0 . 7 0 7 1}$ & 0.7071 & 0.0000 \\
Government spending & 0.7071 & 0.7071 & 0.0000 \\
\hline
\end{tabular}

Table 9 Regulatory efficiency principal components analysis/ correlation

\begin{tabular}{lllll}
\hline Component & Eigenvalue & Difference & Proportion & Cumulative \\
\hline Comp 1 & $\mathbf{1 . 5 1 8 1 4}$ & 0.75454 & 0.5060 & 0.5060 \\
Comp 2 & 0.75454 & 0.02722 & 0.2515 & 0.7576 \\
Comp 3 & 0.72732 & & 0.2424 & 1.0000 \\
\hline
\end{tabular}

No. obs $=704$, No. of components $=3$, trace $=3$, rho $=1$
Table 10 Regulatory efficiency principal components (eigenvectors)

\begin{tabular}{lllll}
\hline Variable & Comp 1 & Comp 2 & Comp 3 & Unexplained \\
\hline Business freedom & $\mathbf{0 . 5 7 3 0}$ & -0.6929 & 0.4377 & 0.0000 \\
Monetary freedom & 0.5718 & 0.7206 & 0.3922 & 0.0000 \\
Labor freedom & 0.5672 & -0.0255 & -0.8091 & 0.0000 \\
\hline
\end{tabular}

Table 11 Market openness principal components analysis/ correlation

\begin{tabular}{lllll}
\hline Component & Eigenvalue & Difference & Proportion & Cumulative \\
\hline Comp 1 & $\mathbf{1 . 7 8 6 5 7}$ & 0.915964 & 0.5955 & 0.5955 \\
Comp 2 & 0.870609 & 0.527791 & 0.2902 & 0.8857 \\
Comp 3 & 0.342818 & & 0.1143 & 1.0000 \\
\hline
\end{tabular}

No. obs $=704$, no. of components $=3$, trace $=3$, rho $=1$

Table 12 Market openness principal components (eigenvectors)

\begin{tabular}{lllll}
\hline Variable & Comp 1 & Comp 2 & Comp 3 & Unexplained \\
\hline Trade freedom & $\mathbf{0 . 9 2 6 6}$ & 0.3759 & 0.0108 & 0.0000 \\
Investment freedom & -0.2736 & 0.6541 & 0.7052 & 0.0000 \\
Financial freedom & -0.2581 & 0.6564 & -0.7089 & 0.0000 \\
\hline
\end{tabular}


Table 13 Data description, measurement, and sources

\begin{tabular}{llll}
\hline Variable & $\begin{array}{l}\text { A priori } \\
\text { expected } \\
\text { sign }\end{array}$ & \\
& &
\end{tabular}

Dependent variable: Renewable energy consumption (\% of total final energy consumption)
Renewable Renewable energy consumption which is measured as the share of renewable energy in total final energy consumption. Source: WDI (2018)

\section{Explanatory variables}

Positive (+) HDI

Property rights

Tax burden

Trade freedom

Business freedom

Economic Structure

Positive ES

$(-)$

Positive (+) PR

Positive (+) TF

Positive (+) BF $(+) /$ negative

Negative (-) TB

*WDI, world development indicators

Table 14 Number and names of countries used

\begin{tabular}{lll}
\hline 1. Algeria & 2. Angola & 3. Botswana \\
\hline 4. Burkina Faso & 5. Cameroon & 6. Congo \\
7. DR Congo & 8. Egypt & 9. Ethiopia \\
10. Gabon & 11. Gambia & 12. Ghana \\
13. Guinea & 14. Guinea-Bissau & 15. Kenya \\
16. Liberia & 17. Malawi & 18. Mali \\
19. Morocco & 20. Mozambique & 21. Namibia \\
22. Nigeria & 23. Senegal & 24. Sierra Leone \\
25. South Africa & 26. Sudan & 27. Tanzania \\
28. Togo & 29. Tunisia & 30. Uganda \\
31. Zambia & 32. Zimbabwe & \\
\hline
\end{tabular}

HDI Real GDP per capita is the annual percentage growth rate of output in constant 2010 local currency divided by the midyear population. Real GDP is measured by the summation of gross value added by all producers in the economy plus net indirect taxes. Source: WDI (2018)

Property rights component assesses the extent to which a country's legal framework allows individuals to accumulate private property freely, secured by clear laws that the government enforces effectively. Relying on a mix of survey data and independent assessments, it provides a quantifiable measure of the degree to which a country's laws protect private property rights and the extent to which those laws are respected. It also assesses the likelihood that private property will be expropriated by the state. It is measured on a scale of 0 (lowest) to 100 (highest).

Source: The Heritage Foundation (2018).

Tax burden is a composite measure that reflects marginal tax rates on both personal and corporate income and the overall level of taxation (including direct and indirect taxes imposed by all levels of government) as a percentage of gross domestic product (GDP). It is measured on a scale of 0 (lowest) to 100 (highest). Source: The Heritage Foundation (2018)

Trade freedom is a composite measure of the extent of tariff and nontariff barriers that affect imports and exports of goods and services. It is measured on a scale of 0 (lowest) to 100 (highest) based on two inputs: The trade-weighted average tariff rate and non-tariff barriers (NTBs). Source: The Heritage Foundation (2018)

The business freedom component measures the extent to which the regulatory and infrastructure environments constrain the efficient operation of businesses. The quantitative score is derived from an array of factors that affect the ease of starting, operating, and closing a business. The business freedom score for each country is a number between 0 and 100, with 100 indicating the freest business environment. Source: The Heritage Foundation (2018)

It is the industry value added as a share of services value added. Source: WDI (2018) 
Table 15 Pairwise correlation matrix

\begin{tabular}{|c|c|c|c|c|c|c|}
\hline & $\mathrm{HDI}$ & Property rights & Business freedom & Trade freedom & Tax burden & Economic structure \\
\hline$\overline{\mathrm{HDI}}$ & 1 & & & & & \\
\hline Property rights & 0.2629 & 1 & & & & \\
\hline Business freedom & 0.4083 & 0.5596 & 1 & & & \\
\hline Trade freedom & 0.1958 & 0.058 & 0.0864 & 1 & & \\
\hline Tax burden & 0.1591 & 0.0096 & -0.032 & 0.4685 & 1 & \\
\hline Economic structure & 0.2666 & 0.0299 & 0.0288 & -0.2198 & 0.0131 & 1 \\
\hline
\end{tabular}

\section{Abbreviations}

PCA: Principal component analysis; SDGs: Sustainable development goals; DOLS: Dynamic ordinary least squares; FOLS: Fully modified ordinary least squares; POLS: Pooled ordinary least squares

\section{Acknowledgements}

The authors are grateful to the Department of Economics, Central University, Ghana. Again, the reviewers have demonstrated excellent knowledge in the subject area, with constructive and well-presented criticisms and opinions. We say a million thanks to the reviewers, chief editor, and the editorial office. This journal is highly recommended for professionalism and excellent delivery of service.

\section{Authors' contributions}

Apart from the original idea which came from the corresponding author, all other sections of the paper including concepts, writing, and proofreading were jointly done by the authors. The author(s) read and approved the final manuscript.

\section{Funding}

The authors received no funding for this study.

\section{Availability of data and materials}

Data and additional materials are available on request.

\section{Ethics approval and consent to participate} N/A

\section{Consent for publication}

All authors have given their consent for this paper to be considered for publication.

\section{Competing interests}

The authors declare that they have no competing interests.

\section{Received: 14 May 2019 Accepted: 6 August 2020}

Published online: 04 September 2020

\section{References}

1. IEA (2018) Renewables 2018 -market analysis and forecast from 2018 to 2023. https://www.iea.org/renewables2018. Accessed 6 May 2019.

2. Demirbas A (2009) Global renewable energy projections. Energ Source Part B 4(2):212-224

3. The World Bank (2006) The road to 2050 -sustainable development for the 21st century. Office of the Publisher, The World Bank, Washington DC

4. World Bank (2018) World development indicators on online (WDI) database. The World Bank, Washington DC

5. Jacqmin J (2018) The role of market-oriented institutions in the deployment of renewable energies: evidences from Europe. Appl Econ 50(2):202-215

6. Sadorsky P (2009) Renewable energy consumption and income in emerging economies. Energ Policy 37(10):4021-4028

7. Ouedraogo NS (2013) Energy consumption and economic growth: evidence from the economic community of West African States (ECOWAS). Energy Econ 36:637-647

8. Ergun SJ, Owusu PA, Rivas MF (2019) Determinants of renewable energy consumption in Africa. Environ Sci Pollut R 26(15):15390-15405
9. Kraft J, Kraft A (1978) On the relationship between energy and GNP. J Energy Dev 3:401-403

10. Steinberger JK, Roberts JT (2010) From constraint to sufficiency: the decoupling of energy and carbon from human needs, 1975-2005. Ecol Econ 70(2):425-433

11. Lambert JG, Hall CAS, Balogh S, Gupta A, Arnold M (2014) Energy, EROI and quality of life. Energ Policy 64:153-167

12. Aïssa MSB, Jebli MB, Youssef SB (2014) Output, renewable energy consumption and trade in Africa. Energ Policy 66:11-18

13. Odhiambo NM (2010) Energy consumption, prices and economic growth in three SSA countries: a comparative study. Energ Policy 38(5):2463-2469

14. Salim RA, Rafiq S (2012) Why do some emerging economies proactively accelerate the adoption of renewable energy? Energy Econ 34(4):1051-1057

15. Apergis N, Payne JE (2014b) Renewable energy, output, $\mathrm{CO}_{2}$ emissions, and fossil fuel prices in Central America: evidence from a nonlinear panel smooth transition vector error correction model. Energy Econ 42:226-232

16. Sadorsky P (2009b) Renewable energy consumption, $\mathrm{CO}_{2}$ emissions and oil prices in the G7 countries. Energy Econ 31(3):456-462

17. Marques AC, Fuinhas JA (2011) Drivers promoting renewable energy: a dynamic panel approach. Renew Sust Energ Rev 15(3):1601-1608

18. Apergis N, Payne JE (2014a) The causal dynamics between renewable energy, real GDP, emissions and oil prices: evidence from OECD countries. Appl Econ 46(36):4519-4525

19. Mehrara M, Rezaei S, Razi HD (2015) Determinants of renewable energy consumption among ECO countries; based on Bayesian model averaging and weighted-average least square. Int Lett Soc Hum Sci 54:96-109

20. Akar BG (2016) The determinants of renewable energy consumption: an empirical analysis for the Balkans. Eur Sci J 12(11):594-607

21. Pfeiffer B, Mulder P (2013) Explaining the diffusion of renewable energy technology in developing countries. Energy Econ 40:285-296

22. Omri A, Daly S, Nguyen DK (2015) A robust analysis of the relationship between renewable energy consumption and its main drivers. Appl Econ 47(28):2913-2923

23. Attiaoui I, Toumi H, Ammouri B, Gargouri I (2017) Causality links among renewable energy consumption, $\mathrm{CO}_{2}$ emissions, and economic growth in Africa: evidence from a panel ARDL-PMG approach. Environ Sci Pollut R 24(14):13036-13048

24. Ackah I, Kizys R (2015) Green growth in oil producing African countries: a panel data analysis of renewable energy demand. Renew Sust Energ Rev 50: 1157-1166

25. da Silva PP, Cerqueira PA, Ogbe W (2018) Determinants of renewable energy growth in Sub-Saharan Africa: evidence from panel ARDL. Energy 156:45-54

26. Gwartney J, Lawson R (2004) Economic freedom, investment, and growth. Economic Freedom of the World. Annual Report 2004. The Fraser Institute, Vancouver

27. Gwartney J, Lawson R (2007) Economic freedom of the world. Annual report 2007. The Fraser Institute, Vancouver

28. Marinescu C, Fucec AA (2014) The impact of economic freedom on renewable energy investments' efficiency. Int Multi Sci Geoco 3:447-454

29. Wu L, Broadstock DC (2015) Does economic, financial and institutional development matter for renewable energy consumption? Evidence from emerging economies. Int J Econ Policy Emerg Econ 8(1):20-39

30. Bhattacharya M, Churchill SA, Paramati SR (2017) The dynamic impact of renewable energy and institutions on economic output and $\mathrm{CO}_{2}$ emissions across regions. Renew Energy 111:157-167 
31. Amuakwa-Mensah F, Klege RA, Adom PK, Amoah A, Hagan E (2018) Unveiling the energy saving role of banking performance in Sub-Sahara Africa. Energy Econ 74:828-842

32. The Heritage Foundation (2018) 2018 index of economic freedom. The Heritage Foundation, Washington DC

33. Mensah JT, Marbuah G, Amoah A (2016) Energy demand in Ghana: a disaggregated analysis. Renew Sust Energ Rev 53:924-935

34. Amoah A, Hughes G, Pomeyie P (2018) Environmental consciousness and choice of bulb for lighting in a developing country. Energy Sustain Sos 8(1):17

35. Kao C, Chiang MH (1998) On the estimation and inference of a cointegrated regression in panel data. Working Paper, Center for Policy Research, Syracuse University.

36. Kao C, Chiang MH (2001) On the estimation and inference of a cointegrated regression in panel data. In Nonstationary panels, panel cointegration, and dynamic panels. Emerald Group Publishing Limited, 15:179-222. http://www. emeraldinsight.com/doi/abs/10.1016/S0731-9053(00)15007-8. Accessed 25 Nov 2018.

37. Pedroni P (1999) Critical values for cointegration tests in heterogeneous panels with multiple regressors. Oxford B Econ Stat 61(S1):653-670

38. Kwablah E, Amoah A, Panin A (2014) The impact of foreign aid on nationa income in Ghana: a test for long-run equilibrium. Afr J Econ Sust Dev 3(3): 215-236

39. Acikgoz B, Amoah A, Yllmazer M (2016) Economic freedom and growth: a panel cointegration approach. Panoeconomicus 63(5):541-562

40. Funk M (2001) Trade and international R\&D spillovers among OECD countries. South Econ J 67(3):725-736

41. Korle K, Amoah A, Hughes G, Pomeyie P, Ahiabor G (2020) Investigating the role of disaggregated economic freedom measures and FDI on human development in Africa. J Econ Admin Sci Vol ahead-of-print: No ahead-ofprint. https://doi.org/10.1108/JEAS-02-2019-0017

42. Zhao X, Luo D (2017) Driving force of rising renewable energy in China: environment, regulation and employment. Renew Sust Energ Rev 68:48-56

43. Ben Jebli M, Ben Youssef S, Ozturk I (2015) The role of renewable energy consumption and trade: environmental Kuznets curve analysis for subSaharan Africa countries. Afr Dev Rev 27(3):288-300

44. Amigun B, Musango JK, Stafford W (2011) Biofuels and sustainability in Africa. Renew Sust Energ Rev 15(2):1360-1372

45. Locke, A. (2013) Property rights and development briefing: property rights and economic growth. Overseas Development Institute. https://www. refworld.org/pdfid/523ab6dc4. pdf. Accessed 25 June 2020.

\section{Publisher's Note}

Springer Nature remains neutral with regard to jurisdictional claims in published maps and institutional affiliations.

Ready to submit your research? Choose BMC and benefit from:

- fast, convenient online submission

- thorough peer review by experienced researchers in your field

- rapid publication on acceptance

- support for research data, including large and complex data types

- gold Open Access which fosters wider collaboration and increased citations

- maximum visibility for your research: over $100 \mathrm{M}$ website views per year

At BMC, research is always in progress.

Learn more biomedcentral.com/submissions 